\title{
IMPROVED COMPOSITION-PROPERTY RELATIONS IN SILICATE GLASSES, PART I: VISCOSITY
}

Alexander Fluegel, Arun K. Varshneya, David A. Earl, Thomas P. Seward, Dolun Oksoy

New York State College of Ceramics

Alfred University

2 Pine Street

Alfred, NY 14802

\section{ABSTRACT}

For the first time, several silicate glass property databases were analyzed without using any a priori knowledge of the details of bonding and lumped as a single group, as a function of the chemical composition. The viscosity of over 300 compositions including soda-lime glasses, borosilicates, glasses with high alkaline earth content, NIST glass viscosity standards, lead silicates, fluorosilicates, and phospho-silicates have been examined. Using multiple regression modeling, linear and multiplicative relations between the chemical composition and several properties, e.g. viscosity, thermal expansion, density, refractive index, electrical conductivity were developed. In this paper the modeling of the viscosity versus composition is discussed. The described relations have been found to link data of different authors and compositions into one global equation which (a) allows validation of glass property datasets, (b) quantifies the influences of glass components and component interactions, and (c) allows some conclusions regarding the nature of glass. The analysis so far makes it possible to estimate the viscosity isokoms at $\log (\eta / \mathrm{Pa} \cdot \mathrm{s})=12.0$ with an error of $\pm 7^{\circ} \mathrm{C}$, at $\log (\eta / \mathrm{Pa} \cdot \mathrm{s})=6.6$ with an error of $\pm 9^{\circ} \mathrm{C}$, and at $\log (\eta / \mathrm{Pa} \cdot \mathrm{s})=1.5$ with an error of $\pm 17^{\circ} \mathrm{C}$. This research was partially funded by the US Department of Energy, Grant DE FG 07-96EE41262.

\section{INTRODUCTION}

This study was started within the framework of a larger project of the NSF Industry/University Center for Glass Research (CGR) to provide the glass industry a database and a method for calculating the properties of technical glasses within the composition and temperature limits of interest, as pioneered in the $19^{\text {th }}$ century by Winkelmann and Schott [1] and summarized recently by Priven and Mazurin [2]. As part of it, the viscosities of 150 industrial glass variations (including float, container, low-expansion borosilicate, TV panel, wool, and textile fiber glasses) have been determined between $\log (\eta / \mathrm{Pa} \cdot \mathrm{s})=1-12$ by various groups. A statistical regression analysis of the results was extended to the data given by Lakatos [3], the NIST viscosity standards SRM 710A, 711, and 717A, as well as viscosity data of Owens-Illinois Glass Company [4], and Allison \& Turner [5]. Common to all sources mentioned is the observation that industrial compositions were investigated systematically, in addition to providing a chemical analysis of the glasses.

\section{EXPERIMENTAL DESIGN AND MEASUREMENT PROCEDURES}

Member companies of the NSF Industry/University Center for Glass Research (CGR) selected six groups of industrial glasses for the study: float, container, low-expansion borosilicate, TV panel, wool, and textile fiber glasses. Starting from one base composition per glass 
group, supplied by CGR member companies, twenty-four further composition variations per group were selected using a Plackett-Burman design based on weight percent. The concentration limits and all oxides of interest were given by CGR member representatives [6]. The glass preparation is described in $[6,7]$.

Viscosity measurements

The viscosity curve over $\log (\eta / \mathrm{Pa} \cdot \mathrm{s})=1-12$ was determined by three methods:

1) Beam bending, $\log (\eta / \mathrm{Pa} \cdot \mathrm{s})=10-12$, by J. E. Shelby, Alfred University, Alfred, NY

2) Parallel plate, $\log (\eta / \mathrm{Pa} \cdot \mathrm{s})=6-9$, by A. Fluegel and A. K. Varshneya, Alfred University

3) Cylinder rotation, $\log (\eta / \mathrm{Pa} \cdot \mathrm{s}) \sim 1-2$, by C. A. See et al., Pacific Northwest Laboratory (PNNL), Redland, WA [8]

The principles of the parallel-plate viscometry are described by Varshneya [9, 10], and details of this study are given in [7]. The beam bending and cylinder rotation measurement procedures, as well as all 150 analyzed glass compositions are summarized in [6]. The viscosity data are listed in Tables VI-VIII. Data at $\log (\eta / \mathrm{Pa} \cdot \mathrm{s})=6.6$ for two alkali-free borosilicates with $\sim 20 \mathrm{~mol} \% \mathrm{SiO}_{2}$ were included in this work at $\log (\eta / \mathrm{Pa} \cdot \mathrm{s})=6.6$ for testing the extension to wider glass composition areas in later studies.

\section{STATISTICAL DATA ANALYSIS}

All concentrations in the databases were converted to mol\%, from the original numbers in $\mathrm{wt} \%$ and molar fraction. The viscosity values were fitted for each investigator separately to the Vogel-Fulcher-Tammann equation (VFT), i.e., the three sources in [6] were not combined for enabling trend and offset analysis. The fits described the experimental data well. Following the VFT fits, for all glasses the temperatures of constant viscosities (isokom) were calculated for $\log (\eta / \mathrm{Pa} \cdot \mathrm{s})=1.5,6.6$, and $12.0(\sim \mathrm{Tg})$. The cylinder rotation measurements done by $\mathrm{C}$. A. See et al. at PNNL [6] had to be analyzed with exceptional care, firstly because the original data vary significantly in the viscosity levels examined for $\log (\eta / \mathrm{Pa} \cdot \mathrm{s})<2.6$, and secondly because the number of datapoints was only 2-4 for each glass. If 3 or 4 datapoints were reported to cover the range around $\log (\eta / \mathrm{Pa} \cdot \mathrm{s})=1.5 \pm 0.25$, a VFT fit was used, else a linear fit with 2 datapoints was employed. In $\sim 20 \%$ of all cases however the reported viscosity levels were far off from $\log (\eta / \mathrm{Pa} \cdot \mathrm{s})=1.5$. Then, a datapoint from parallel plate measurements at $\log (\eta / \mathrm{Pa} \cdot \mathrm{s})=6.0$, obtained by Fluegel and Varshneya at Alfred University [6], was included in the VFT fit. As a result, the cylinder rotation measurements done at PNNL may appear less accurate than other data.

Multiple regression model type and factors

A slack-variable model with variable intercept including multiplicative interactions and excluding silica was used (Eq. (1) [11]. The independent variables were the concentrations in mol\% (single-component factors) and the multiplicative interactions (interaction factors); the dependent variables were the isokom temperatures in ${ }^{\circ} \mathrm{C}$ for $\log (\eta / \mathrm{Pa} \cdot \mathrm{s})=1.5,6.6$, and 12.0. No squared terms were considered because of correlations with single-component factors.

$$
\mathrm{T}(\text { isokom })=\mathrm{K} 0+\sum_{\mathrm{j}=1}^{\mathrm{n}}\left\{\mathrm{K} 1_{\mathrm{j}} \cdot \mathrm{C}_{\mathrm{j}}+\sum_{\mathrm{k}=\mathrm{j}+1}^{\mathrm{n}}\left(\mathrm{K} 2_{\mathrm{k}} \cdot \mathrm{C}_{\mathrm{j}} \cdot \mathrm{C}_{\mathrm{k}}+\sum_{\mathrm{m}=\mathrm{j}+\mathrm{k}+1}^{\mathrm{n}} \mathrm{K} 3_{\mathrm{m}} \cdot \mathrm{C}_{\mathrm{j}} \cdot \mathrm{C}_{\mathrm{k}} \cdot \mathrm{C}_{\mathrm{m}}\right)\right\}
$$


K0-K3 in the model equation Eq. (1) are the coefficients, with K0 being the intercept, K1 the single-component coefficients, K2 the coefficients of two-component interaction coefficients, and $\mathrm{K} 3$ the coefficients of three-component interactions. The variable $\mathrm{n}$ in Eq. (1) is the total number of glass components (excluding silica); $\mathrm{j}, \mathrm{k}$, and $\mathrm{m}$ are individual numbers of the glass components, and $\mathrm{C}$ are the concentrations in mol\%.

The difference (observed - calculated) value is defined as residual.

The model type used in this study implies that all glasses are based on silica. In other words, all single-component and interaction coefficients in this work are in fact interaction coefficients with silica. Therefore silica-free glasses might not fit into this study.

Table I: Concentration limits in mol\% and frequency of glass components used for the model at $\log (\eta / \mathrm{Pa} \cdot s)=6.6$; Minimum in each range is always zero except $\mathrm{C}\left(\mathrm{SiO}_{2}\right)_{\min }=20 \mathrm{~mol} \% ; \sigma$ is the standard deviation of the concentration population. Outliers were not counted.

\begin{tabular}{|l|c|c|c|c||}
\hline Component & Maximum in mol\% & Average in mol\% & $\sigma$ in mol\% & \# with C $>0.5$ mol\% \\
\hline \hline $\mathrm{SiO}_{2}$ & 87.10 & 69.66 & 7.10 & 297 \\
\hline $\mathrm{B}_{2} \mathrm{O}_{3}$ & 16.97 & 1.90 & 3.74 & 93 \\
\hline $\mathrm{Al}_{2} \mathrm{O}_{3}$ & 9.99 & 1.62 & 2.31 & 167 \\
\hline $\mathrm{MgO}$ & 16.90 & 3.96 & 3.24 & 230 \\
\hline $\mathrm{CaO}$ & 28.05 & 8.52 & 5.51 & 271 \\
\hline $\mathrm{SrO}$ & 7.03 & 0.29 & 1.30 & 22 \\
\hline $\mathrm{BaO}$ & 30.30 & 0.52 & 2.69 & 40 \\
\hline $\mathrm{Li}{ }_{2} \mathrm{O}$ & 11.81 & 0.25 & 1.22 & 27 \\
\hline $\mathrm{Na}_{2} \mathrm{O}$ & 18.32 & 11.21 & 4.22 & 285 \\
\hline $\mathrm{K}_{2} \mathrm{O}$ & 6.84 & 1.17 & 1.78 & 131 \\
\hline $\mathrm{TiO}_{2}$ & 0.82 & 0.10 & 0.22 & 23 \\
\hline $\mathrm{ZrO}_{2}$ & 1.76 & 0.07 & 0.33 & 14 \\
\hline $\mathrm{PbO}^{2}$ & 18.90 & 0.09 & 1.11 & 10 \\
\hline $\mathrm{ZnO}^{\mathrm{F}}$ & 4.00 & 0.14 & 0.57 & 23 \\
\hline $\mathrm{Fe}_{2} \mathrm{O}_{3}$ & 10.31 & 0.34 & 0.99 & 44 \\
\hline $\mathrm{Y}_{2} \mathrm{O}_{3}$ & 1.92 & 0.12 & 0.32 & 23 \\
\hline $\mathrm{CeO}_{2}$ & 2.00 & 0.01 & 0.16 & 2 \\
\hline $\mathrm{SO}_{3}$ & 0.30 & 0.01 & 0.05 & 0 \\
\hline $\mathrm{P}_{2} \mathrm{O}_{5}$ & 0.29 & 0.03 & 0.06 & 0 \\
\hline $\mathrm{Se}_{\mathrm{Cr}_{2} \mathrm{O}_{3}}$ & 0.85 & 0.01 & 0.08 & 0 \\
\hline $\mathrm{Co}_{3} \mathrm{O}_{4}$ & 0.05 & 0.00 & 0.00 & 0 \\
\hline $\mathrm{H}_{2} \mathrm{O}_{*}$ & $642 *$ & 0.01 & 0.03 & 0 \\
\hline
\end{tabular}

The single-component factors in this work and the concentration limits for the model at $\log (\eta / \mathrm{Pa} \cdot \mathrm{s})=6.6$ are summarized in Table I. The models at $\log (\eta / \mathrm{Pa} \cdot \mathrm{s})=1.5$ and 12.0 have

\footnotetext{
* All water concentrations listed in Table I are in ppm weight, determined by J. E. Shelby using infrared spectroscopy. The values are valid only for the 150 glasses in reference [6]. The minimum water concentration measured was $80 \mathrm{ppm}$ weight.
} 
similar concentration limits [12]. Neglected were minor components with $\mathrm{C}<0.5 \mathrm{~mol} \%$, because initial analyses proved their insignificance at these low levels: $\mathrm{FeO}, \mathrm{Cr}_{2} \mathrm{O}_{3}, \mathrm{Co}_{3} \mathrm{O}_{4}, \mathrm{CeO}_{2}, \mathrm{Sb}_{2} \mathrm{O}_{3}$, $\mathrm{As}_{2} \mathrm{O}_{3}, \mathrm{Se}, \mathrm{SO}_{3}$ and $\mathrm{H}_{2} \mathrm{O} *$ (Table I). All two-component interactions of the following components were considered if the interaction occurred more than twenty five times: $\mathrm{B}_{2} \mathrm{O}_{3}, \mathrm{Al}_{2} \mathrm{O}_{3}$, $\mathrm{MgO}, \mathrm{CaO}, \mathrm{SrO}, \mathrm{BaO}, \mathrm{Li}_{2} \mathrm{O}, \mathrm{Na}_{2} \mathrm{O}, \mathrm{K}_{2} \mathrm{O}$, and $\mathrm{F}$. In addition, all three-component interactions of the components $\mathrm{B}_{2} \mathrm{O}_{3}, \mathrm{Al}_{2} \mathrm{O}_{3}, \mathrm{MgO}, \mathrm{CaO}, \mathrm{Na}_{2} \mathrm{O}$, and $\mathrm{K}_{2} \mathrm{O}$ were taken into account. The interaction limits, i.e. the quantitative limits of component combinations, are summarized in [12]. The interaction limits need to be considered before any calculation.

Dataset-specific correction factors

To the six datasets analyzed in this study (Shelby, Fluegel, See, Lakatos, Owens-Illinois, Allison), dataset specific correction factors were assigned:

Trend correction:

$\mathrm{T}($ isokom $)$, observed $=\mathrm{T}($ isokom $)$, calculated $+\mathrm{K}_{\mathrm{DT}} \times \mathrm{T}($ isokom $)$, observed

Offset correction:

$\mathrm{T}($ isokom $)$, observed $=\mathrm{T}($ isokom $)$, calculated $+\mathrm{K}_{\mathrm{DO}}$

All dataset-specific correction coefficients $\mathrm{K}_{\mathrm{DT}}$ and $\mathrm{K}_{\mathrm{DO}}$ were set to zero in the beginning. In case the data analysis described below resulted in significant trends or offsets of the residuals vs. the observed values, either $\mathrm{K}_{\mathrm{DT}}$ or $\mathrm{K}_{\mathrm{DO}}$ per dataset were allowed to vary. $\mathrm{K}_{\mathrm{DT}}$ and $\mathrm{K}_{\mathrm{DO}}$ were never varied simultaneously for one dataset because of strong correlation.

Modeling procedure

Before starting the multiple regression calculation, all single-component and interaction factors were checked for linear correlations (Pearson's matrix). Strongly correlated factors with absolute correlations $>0.8$ were excluded from the model according to the hierarchy, the frequency of $\mathrm{C}>0.5 \mathrm{~mol} \%$, and the factor average over all glasses. This procedure reduced the $\sim 90$ considered variables to $\sim 55$.

Multiple regression analysis was done in the programs MCA (Nextbridge Softwares, version 1999), as well as SPSS (Standard version for Windows, release 11.5.0, 6 Sept 2002, LEAD Technologies Inc).

Factors were excluded stepwise from the model if there was less than a $\sim 95 \%$ confidence level in their significance ( $t$-value $<2$ ). After exclusion of all insignificant factors, the datasets were checked for trends (i.e. if the residual depended on the viscosity) and offsets (i.e. if the average of all residuals for one dataset was significantly different from zero). Trends and offsets in datasets were considered by corresponding dataset-specific correction factors according to Eq. (2) and Eq. (3), and summarized in Table II. Next, outlying data were analyzed. If the residual was larger than three times the model error, i.e. if the standardized residual was larger than three, the value was considered an outlier and deleted from the model. Finally, the complete modeling procedure was iterated, beginning from the correlation analysis until no further outlier could be found.

\section{RESULTS}

Table II shows the dataset properties, e. g. the total number of glasses and viscosity levels investigated, trends, offsets, etc. In addition, Table II presents the standard deviation $\sigma$ of all

\footnotetext{
* Even though $\mathrm{H}_{2} \mathrm{O}$ is reported to strongly influence the viscosity [23], it was insignificant in this study.
} 
residuals per dataset, which is related to the dataset consistency within itself, i.e., its precision. The dataset specific correction factors, combined with the percentage of outliers per dataset, and the standard deviation of all residuals per dataset give an estimate of the comparability of a dataset in relation to other datasets, i.e. the total dataset quality.

Tables III, IV, and V list all significant coefficients, as well as their standard errors, t-values, and excluded strong correlations $>0.8$. Insignificant factors and their correlations are not mentioned. The t-values reveal the factor significance; the standard errors reflect the coefficient accuracy. The excluded strong correlated factors might be significant in reality, but the mentioned interferences make it impossible to detect them based on the used composition matrix. Therefore any correlated factor coefficient is the sum of all correlated influences, whereby the most important one is stated as the factor name.

The coefficients in Tables III, IV, and V are valid only within the concentration and interaction limits stated in Table I and [12]. The models in this paper are valid for homogeneous, clear or colored glasses with insignificant crystal content and phase separation. The best viscosity isokom predictions are possible if all factors are within $\pm 2 \sigma$ (standard deviation) of the considered factor.

Table II: Dataset properties $(F l=$ Fluegel, $S h=$ Shelby $)$

\begin{tabular}{|c|c|c|c|c|c|c|}
\hline $\begin{array}{c}\text { Data } \\
\text { source }\end{array}$ & $\begin{array}{c}\text { \# of } \\
\text { data }\end{array}$ & $\begin{array}{c}\text { Viscosity level } \\
\text { in } \log (\eta / \mathrm{Pa} \cdot \mathrm{s})\end{array}$ & $\begin{array}{c}\text { Offset } \\
\text { in }{ }^{\circ} \mathrm{C}\end{array}$ & Trend & $\begin{array}{c}\sigma \text { of re- } \\
\text { siduals }\end{array}$ & $\begin{array}{c}\text { of out- } \\
\text { liers }\end{array}$ \\
\hline$[3]$ & 30 & 1.5 & 0 & 0 & 5.1 & 0 \\
\hline$[3]$ & 30 & 6.6 & 0 & 0 & 3.9 & 0 \\
\hline$[3]$ & 30 & 12.0 & 0 & 0 & 3.5 & 0 \\
\hline$[5]$ & 28 & 1.5 & -50.0 & 0 & 13.2 & 0 \\
\hline$[5]$ & 28 & 6.6 & -14.2 & 0 & 5.7 & 0 \\
\hline$[5]$ & 28 & 12.0 & -9.5 & 0 & 4.3 & 0 \\
\hline$[4]$ & 102 & 1.5 & 0 & 0 & 16.3 & 8 \\
\hline$[4]$ & 102 & 6.6 & 0 & 0.0063 & 7.2 & 8 \\
\hline$[6,8]-S e e$ & $147 *$ & 1.5 & 0 & 0 & 18.1 & 21 \\
\hline$[6]-F 1$ & 146 & 6.6 & 0 & 0 & 10.4 & 6 \\
\hline$[6]-S h$ & 136 & 12.0 & 0 & 0.0119 & 7.9 & 9 \\
\hline
\end{tabular}

Viscosity prediction; a calculation example

Since Eq. (1) and the large number of coefficients in Tables III, IV, and V may appear very complicated at first sight, the viscosity prediction for the Standard Reference Material 710A is illustrated here as example (Certificate from: National Institute of Standards \& Technology (NIST), Gaithersburg, MD, 20899, USA; March 20, 1991):

1) The standard 710A is known to be a homogeneous, clear glass, which is a condition for applying the models in this paper.

2) Next, the glass composition in mol\% is obtained from the certificate. The mol\% composition is: $71.37 \mathrm{SiO}_{2}, 1.31 \mathrm{Al}_{2} \mathrm{O}_{3}, 9.62 \mathrm{CaO}, 8.25 \mathrm{Na}_{2} \mathrm{O}, 6.27 \mathrm{~K} \mathrm{O}_{2}, 2.81 \mathrm{ZnO}, 0.32$ $\mathrm{TiO}_{2}, 0.04 \mathrm{Sb}_{2} \mathrm{O}_{3}, 0.02 \mathrm{As}_{2} \mathrm{O}_{3}$. These lie within the acceptable ranges [12].

\footnotetext{
* 24 of 147 values were extrapolated (s. appendix, Table VI).
} 
Table III: Significant model coefficients, $\log (\eta / \mathrm{Pa} \cdot \mathrm{s})=1.5$

\begin{tabular}{|c|c|c|c|c|c|}
\hline Factor & Coefficient & St. error & $\mathrm{t}$ & $\#>0.5$ & Excluded correlations \\
\hline \multicolumn{6}{|c|}{ Single-component coefficients (K1) } \\
\hline $\mathrm{B}_{2} \mathrm{O}_{3}$ & -13.49 & 0.97 & -13.90 & 76 & / \\
\hline $\mathrm{Al}_{2} \mathrm{O}_{3}$ & 4.35 & 1.76 & 2.47 & 155 & $\mathrm{Al}_{2} \mathrm{O}_{3} * \mathrm{CaO}$ \\
\hline $\mathrm{MgO}$ & -5.99 & 0.80 & -7.53 & 225 & $\mathrm{MgO} * \mathrm{Na}_{2} \mathrm{O}$ \\
\hline $\mathrm{CaO}$ & -18.00 & 0.71 & -25.29 & 259 & $\mathrm{Al}_{2} \mathrm{O}_{3} * \mathrm{CaO}$ \\
\hline $\mathrm{SrO}$ & -20.09 & 1.05 & -19.08 & 24 & $\begin{array}{l}\mathrm{Al}_{2} \mathrm{O}_{3} * \mathrm{SrO}, \mathrm{SrO} * \mathrm{BaO} \\
\mathrm{SrO} * \mathrm{Na}_{2} \mathrm{O}, \mathrm{SrO} * \mathrm{~K}_{2} \mathrm{O}\end{array}$ \\
\hline $\mathrm{BaO}$ & -22.26 & 1.19 & -18.63 & 37 & $\begin{array}{c}\mathrm{Al}_{2} \mathrm{O}_{3} * \mathrm{BaO}, \mathrm{BaO}^{*} \mathrm{Na}_{2} \mathrm{O}, \\
\mathrm{BaO} * \mathrm{~K}_{2} \mathrm{O}\end{array}$ \\
\hline $\mathrm{Li}_{2} \mathrm{O}$ & -29.14 & 0.90 & -32.38 & 28 & $\begin{array}{c}\mathrm{MgO} * \mathrm{Li}_{2} \mathrm{O}, \mathrm{CaO}^{*} \mathrm{Li}_{2} \mathrm{O} \\
\mathrm{Li}_{2} \mathrm{O} * \mathrm{Na}_{2} \mathrm{O}\end{array}$ \\
\hline $\mathrm{Na}_{2} \mathrm{O}$ & -25.10 & 0.79 & -31.79 & 271 & $\mathrm{Na}_{2} \mathrm{O} * \mathrm{~F}$ \\
\hline $\mathrm{K}_{2} \mathrm{O}$ & -19.21 & 1.12 & -17.20 & 124 & $\mathrm{Na}_{2} \mathrm{O} * \mathrm{~K}_{2} \mathrm{O}$ \\
\hline $\mathrm{PbO}$ & -23.22 & 1.00 & -23.25 & 12 & I \\
\hline $\mathrm{ZnO}$ & -9.42 & 1.92 & -4.91 & 22 & 1 \\
\hline $\mathrm{F}$ & -14.73 & 1.82 & -8.11 & 45 & $\mathrm{MgO}^{*} \mathrm{~F}$ \\
\hline $\mathrm{Fe}_{\mathrm{x}} \mathrm{O}_{\mathrm{y}}$ & -15.33 & 3.24 & -4.74 & 23 & I \\
\hline \multicolumn{6}{|c|}{ Two-component interaction coefficients (K2) } \\
\hline $\mathrm{B}_{2} \mathrm{O}_{3} * \mathrm{CaO}$ & -0.225 & 0.050 & -4.48 & 75 & $\begin{array}{c}\mathrm{B}_{2} \mathrm{O}_{3} * \mathrm{Al}_{2} \mathrm{O}_{3} \\
\mathrm{~B}_{2} \mathrm{O}_{3} * \mathrm{Al}_{2} \mathrm{O}_{3} * \mathrm{CaO}\end{array}$ \\
\hline $\mathrm{B}_{2} \mathrm{O}_{3} * \mathrm{Na}_{2} \mathrm{O}$ & -0.536 & 0.078 & -6.86 & 76 & l \\
\hline $\mathrm{Al}_{2} \mathrm{O}_{3} * \mathrm{MgO}$ & -0.526 & 0.151 & -3.49 & 180 & $\mathrm{Al}_{2} \mathrm{O}_{3} * \mathrm{MgO} * \mathrm{CaO}$ \\
\hline $\mathrm{Al}_{2} \mathrm{O}_{3} * \mathrm{Na}_{2} \mathrm{O}$ & 0.761 & 0.152 & 5.00 & 258 & $\mathrm{Al}_{2} \mathrm{O}_{3} * \mathrm{CaO}^{*} \mathrm{Na}_{2} \mathrm{O}$ \\
\hline $\mathrm{MgO} * \mathrm{~K}_{2} \mathrm{O}$ & 0.788 & 0.248 & 3.18 & 109 & $\mathrm{MgO} * \mathrm{Na}_{2} \mathrm{O} * \mathrm{~K}_{2} \mathrm{O}$ \\
\hline $\mathrm{CaO} * \mathrm{Na}_{2} \mathrm{O}$ & 0.215 & 0.071 & 3.02 & 257 & 1 \\
\hline $\mathrm{CaO} * \mathrm{~F}$ & 1.017 & 0.222 & 4.58 & 40 & / \\
\hline \multicolumn{6}{|c|}{ Three-component interaction coefficients (K3) } \\
\hline $\mathrm{MgO} * \mathrm{CaO} * \mathrm{Na}_{2} \mathrm{O}$ & -0.0211 & 0.0072 & -2.94 & 232 & l \\
\hline \multicolumn{6}{|c|}{ Dataset-specific correction coefficients for datasets with trends or offsets } \\
\hline Offset for ref. [5] & -50.01 & 3.77 & -13.25 & 28 & 1 \\
\hline
\end{tabular}

Intercept $(\mathrm{K} 0)=(1816.4 \pm 11.4)^{\circ} \mathrm{C} ;$ Standard model error $=16.71^{\circ} \mathrm{C} ; \mathrm{R}^{2}=0.961$ Adequate precision $=$ signal $/$ noise ratio $=(\max$. prediction - min. prediction $) /$

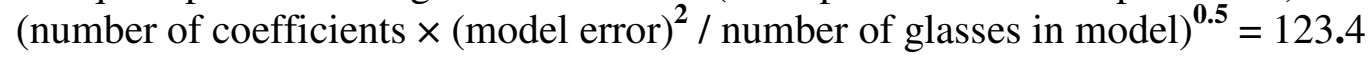

3) For the viscosity level $\log (\eta / \mathrm{Pa} \cdot \mathrm{s})=1.5$, the coefficients from Table III are:: $\mathrm{K} 0=$ 1816.4, $\mathrm{K} 1\left(\mathrm{Al}_{2} \mathrm{O}_{3}\right)=4.35, \mathrm{~K} 1(\mathrm{CaO})=-18.00, \mathrm{~K} 1\left(\mathrm{Na}_{2} \mathrm{O}\right)=-25.10, \mathrm{~K} 1\left(\mathrm{~K}_{2} \mathrm{O}\right)=-19.21$, $\mathrm{K} 1(\mathrm{ZnO})=-9.42, \mathrm{~K} 2\left(\mathrm{Al}_{2} \mathrm{O}_{3} * \mathrm{Na}_{2} \mathrm{O}\right)=0.761, \mathrm{~K} 2\left(\mathrm{CaO}^{*} \mathrm{Na}_{2} \mathrm{O}\right)=0.215$. All remaining coefficients in Table III do not apply for 710A. Since no coefficients are mentioned in Table III for $\mathrm{TiO}_{2}, \mathrm{Sb}_{2} \mathrm{O}_{3}$, and $\mathrm{As}_{2} \mathrm{O} 3$, those minor components must be neglected for the isokom calculation at the viscosity level $\log (\eta / \mathrm{Pa} \cdot \mathrm{s})=1.5$. The same procedure has to be repeated with the coefficients from Tables IV and V. It should be noted that in 
Table IV: Significant model coefficients, $\log (\eta / P a \cdot s)=6.6$

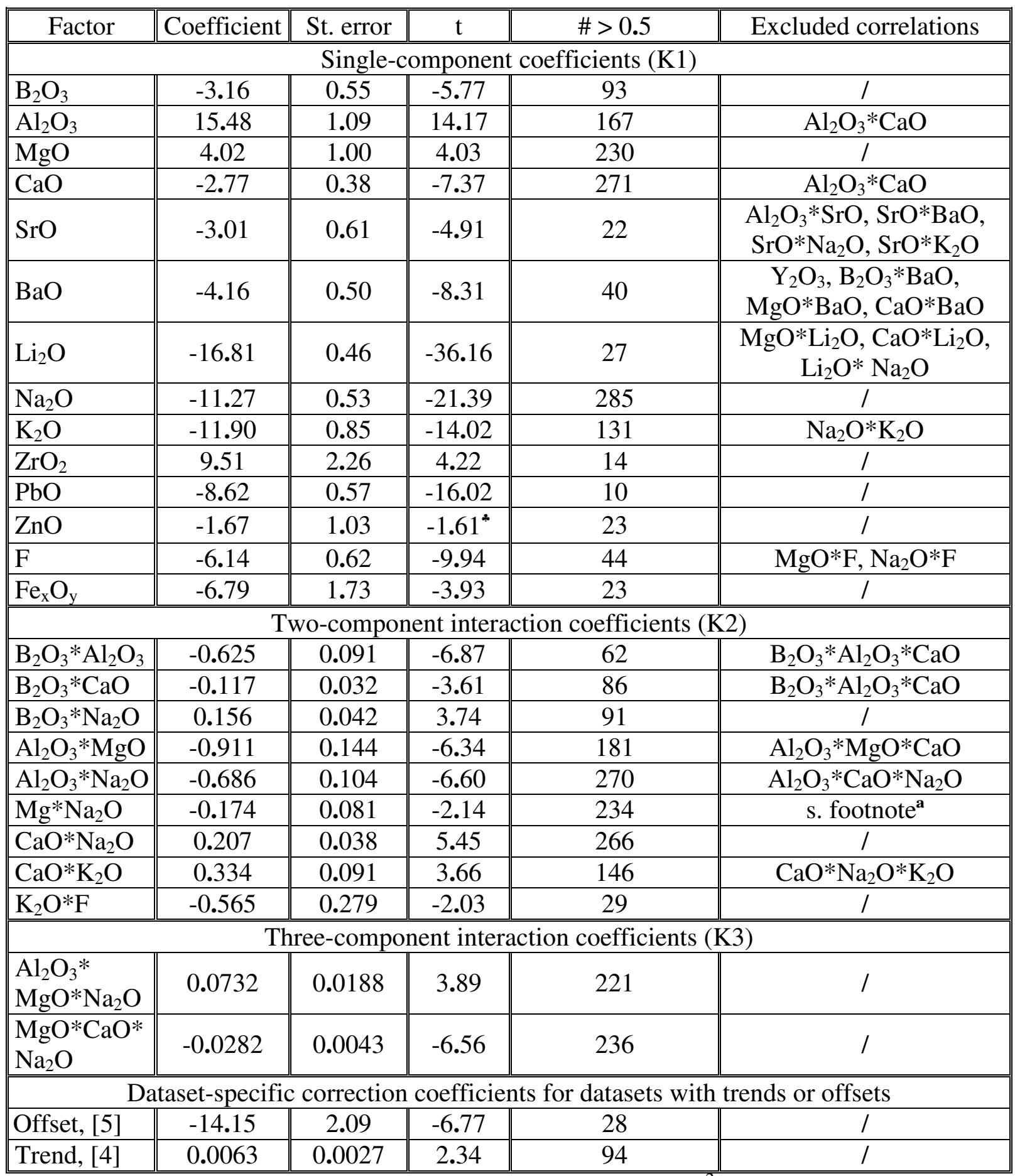

Intercept $(\mathrm{K} 0)=(876.7 \pm 6.6)^{\circ} \mathrm{C} ;$ Standard model error $=8.94^{\circ} \mathrm{C} ; \mathrm{R}^{2}=0.974$

$\mathrm{T}($ isokom, average $)=727.1^{\circ} \mathrm{C} ; \sigma$ of all $\mathrm{T}($ isokom $)$ values $=53.4^{\circ} \mathrm{C} ;$ signal $/$ noise ratio $=136.4$

* $\mathrm{ZnO}$ factor not excluded despite $\mathrm{t}<2$, since it may be needed for glasses with increased $\mathrm{ZnO}$ concentrations.

a The $\mathrm{MgO} * \mathrm{Na}_{2} \mathrm{O}$ interaction is correlated with $\mathrm{MgO}$. The correlation coefficient is 0.83 . The $\mathrm{MgO}^{*} \mathrm{Na}_{2} \mathrm{O}$ interaction was not excluded from the model because of its high frequency (234). 
Table V: Significant model coefficients, $\log (\eta / P a \cdot s)=12.0$

\begin{tabular}{|c|c|c|c|c|c|}
\hline Factor & Coefficient & St. error & $\mathrm{t}$ & $\#>0.5$ & Excluded correlations \\
\hline \multicolumn{6}{|c|}{ Single-component coefficients (K1) } \\
\hline $\mathrm{B}_{2} \mathrm{O}_{3}$ & -3.10 & 0.85 & -3.67 & 62 & I \\
\hline $\mathrm{Al}_{2} \mathrm{O}_{3}$ & 11.24 & 0.74 & 15.28 & 153 & $\mathrm{Al}_{2} \mathrm{O}_{3} * \mathrm{CaO}$ \\
\hline $\mathrm{MgO}$ & -1.54 & 0.27 & -5.73 & 127 & $\mathrm{MgO} * \mathrm{CaO}$ \\
\hline $\mathrm{CaO}$ & 1.05 & 0.28 & 3.80 & 167 & $\mathrm{Al}_{2} \mathrm{O}_{3} * \mathrm{CaO}$ \\
\hline $\mathrm{SrO}$ & 2.25 & 0.48 & 4.67 & 23 & $\mathrm{Al}_{2} \mathrm{O}_{3} * \mathrm{SrO}$ \\
\hline $\mathrm{Li}_{2} \mathrm{O}$ & -21.06 & 1.13 & -18.70 & 25 & $\begin{array}{c}\mathrm{Al}_{2} \mathrm{O}_{3} * \mathrm{Li}_{2} \mathrm{O}, \mathrm{CaO} * \mathrm{Li}_{2} \mathrm{O} \\
\mathrm{Li}_{2} \mathrm{O} * \mathrm{Na}_{2} \mathrm{O}\end{array}$ \\
\hline $\mathrm{Na}_{2} \mathrm{O}$ & -7.30 & 0.47 & -15.48 & 179 & / \\
\hline $\mathrm{K}_{2} \mathrm{O}$ & -11.94 & 0.86 & -13.93 & 112 & $\mathrm{Na}_{2} \mathrm{O} * \mathrm{~K}_{2} \mathrm{O}$ \\
\hline $\mathrm{ZrO}_{2}$ & 9.03 & 1.86 & 4.87 & 12 & I \\
\hline $\mathrm{PbO}$ & -4.61 & 0.46 & -10.11 & 11 & l \\
\hline $\mathrm{F}$ & -9.33 & 0.86 & -10.82 & 34 & $\mathrm{Na}_{2} \mathrm{O} * \mathrm{~F}$ \\
\hline \multicolumn{6}{|c|}{ Two-component interaction coefficients (K2) } \\
\hline $\mathrm{B}_{2} \mathrm{O}_{3} * \mathrm{Al}_{2} \mathrm{O}_{3}$ & -0.626 & 0.112 & -5.60 & 51 & $\mathrm{~B}_{2} \mathrm{O}_{3} * \mathrm{Al}_{2} \mathrm{O}_{3} * \mathrm{CaO}$ \\
\hline $\mathrm{B}_{2} \mathrm{O}_{3} * \mathrm{Na}_{2} \mathrm{O}$ & 0.573 & 0.084 & 6.78 & 63 & I \\
\hline $\mathrm{B}_{2} \mathrm{O}_{3} * \mathrm{~K}_{2} \mathrm{O}$ & 0.585 & 0.119 & 4.93 & 36 & $\mathrm{~B}_{2} \mathrm{O}_{3} * \mathrm{Al}_{2} \mathrm{O}_{3} * \mathrm{~K}_{2} \mathrm{O}$ \\
\hline $\mathrm{CaO} * \mathrm{Na}_{2} \mathrm{O}$ & 0.157 & 0.039 & 4.08 & 164 & I \\
\hline $\mathrm{CaO}^{*} \mathrm{~K}_{2} \mathrm{O}$ & 0.468 & 0.088 & 5.33 & 127 & $\mathrm{CaO} * \mathrm{Na}_{2} \mathrm{O} * \mathrm{~K}_{2} \mathrm{O}$ \\
\hline \multicolumn{6}{|c|}{ Three-component interaction coefficients (K3) } \\
\hline $\mathrm{B}_{2} \mathrm{O}_{3} * \mathrm{Al}_{2} \mathrm{O}_{3} * \mathrm{Na}_{2} \mathrm{O}$ & -0.0449 & 0.0131 & -3.43 & 54 & I \\
\hline $\mathrm{B}_{2} \mathrm{O}_{3} * \mathrm{CaO}^{*} \mathrm{Na}_{2} \mathrm{O}$ & -0.0111 & 0.0054 & -2.07 & 54 & I \\
\hline $\mathrm{Al}_{2} \mathrm{O}_{3} * \mathrm{CaO} * \mathrm{Na}_{2} \mathrm{O}$ & -0.0285 & 0.0063 & -4.50 & 154 & I \\
\hline \multicolumn{6}{|c|}{ Dataset-specific correction coefficients for datasets with trends or offsets } \\
\hline Offset for ref. [5] & -9.48 & 2.52 & -3.76 & 28 & 1 \\
\hline Trend for ref. [6] & 0.0119 & 0.0041 & 2.90 & 127 & I \\
\hline
\end{tabular}

Intercept $(\mathrm{K} 0)=(618.4 \pm 6.5)^{\circ} \mathrm{C} ;$ Standard model error $=7.24^{\circ} \mathrm{C} ; \mathrm{R}^{2}=0.983$

$\mathrm{T}($ isokom, average $)=561.7^{\circ} \mathrm{C} ; \sigma$ of all $\mathrm{T}($ isokom $)$ values $=52.2^{\circ} \mathrm{C} ;$ signal $/$ noise ratio $=123.8$

Table $\mathrm{V}$ one three-component coefficient needs to be considered: $\mathrm{K} 3\left(\mathrm{Al}_{2} \mathrm{O}_{3} * \mathrm{CaO} *\right.$ $\left.\mathrm{Na}_{2} \mathrm{O}\right)=-0.0285$.

4) Next, all single-components coefficients must be multiplied with the applicable concentrations, the obtained products have to be added, as well as the intercept. For glass $710 \mathrm{~A}$ at $\log (\eta / \mathrm{Pa} \cdot \mathrm{s})=1.5$, the single-component contribution is:

$1816.4+4.35 \times 1.31-18.00 \times 9.62-25.10 \times 8.25-19.21 \times 6.27-9.42 \times 2.81=1294.95$

5) Next, add the applicable 2 , and/or 3 - interaction coefficients from Table III multiplied by the corresponding mol\% composition. The result is:

$1294.95+0.761 \times 1.31 \times 8.25+0.215 \times 9.62 \times 8.25=1320$, which is the temperature in ${ }^{\circ} \mathrm{C}$ at which the viscosity of the glass $710 \mathrm{~A}$ is predicted to be $\log (\eta / \mathrm{Pa} \cdot \mathrm{s})=1.5$.

6) Similarly for $\log (\eta / \mathrm{Pa} \cdot \mathrm{s})=6.6$ we obtain $727^{\circ} \mathrm{C}$ using the coefficients in Table IV, and for $\log (\eta / \mathrm{Pa} \cdot \mathrm{s})=12.0$ we obtain $546^{\circ} \mathrm{C}$ using the coefficients in Table V. 
7) By fitting the three temperature-viscosity points from step 6) to the VFT equation, we attain the complete viscosity curve: $\log (\eta / \mathrm{Pa} \cdot \mathrm{s})=-2.753+4625 /\left(\mathrm{T}\right.$ in $\left.{ }^{\circ} \mathrm{C}-232.5\right)$. Those findings are the same as the data in the original NIST certificate within the range of the model errors established in this work.

Compared to viscosity data of investigators not included in this study [16-19], the models in this work result in the same findings approximately within the error ranges stated in Tables III-V.

\section{DISCUSSION}

The principle of the viscosity models presented in this study is proposed as a basis for the systematization of glass property data in the literature. To the authors' knowledge, the models in this paper are based on more data than in any previous work, without having any a priori knowledge of the details of bonding, e.g. as in [13, 14]. The models presented are mathematical in principle, and as a result they are able to incorporate various glass structures. For technical glasses the models in this study are superior to previous works $[3,7,11,15,16]$ by maintaining or improving the prediction accuracy, and/or by extending the composition area covered, and through an advanced data analysis technique.

Multiple regression on mol\% basis allows separating various influences: The interaction coefficients in combination with those for single components confirm that glass is neither an ideal random mixture of its components, nor a perfectly stoichiometric chemical compound, but an intermediate of both. Preferred short-range and intermediate-range structures exist, in addition to having the influences of single components.

The NIST viscosity standards 711, 710A, and 717A fit well into the models with residuals less than $4^{\circ} \mathrm{C}$. The only exception occurs for $717 \mathrm{~A}$ at $\log (\eta / \mathrm{Pa} \cdot \mathrm{s})=1.5$ where the residual is $-9.5^{\circ} \mathrm{C}$. The standards 711 and $717 \mathrm{~A}$ are the only glasses that have a significantly higher influence (leverage) on the model results at $\log (\eta / \mathrm{Pa} \cdot \mathrm{s})=1.5$ and 6.6 respectively than all other glasses; the Cook distances $[20,21]$ are higher than one. A model extension to additional borosilicate glasses and lead silicates, as well as an exact chemical analysis of 711 and 717A may reduce the leverage.

Viscosity values of investigators in the literature that fall into the composition and interaction ranges of this work, but with viscosity isokom residuals larger than three times the model errors in Tables III, IV, and V may be questionable and should be analyzed further.

The large offsets in the data from Allison \& Turner [5], determined in the models presented in this work (Tables III, IV, V), need further examination despite appearing to be thorough. Little is said regarding the calibration of the $\mathrm{Pt} / \mathrm{Pt}-\mathrm{Rh}$ thermocouple data acquisition system and pyrometer used. Also, no viscosity standard had been established yet by the time the paper [5] was published. The two trend coefficients in Table II are just on the limit to be significant, and it is hardly possible to distinguish them from offset corrections of $\sim 5^{\circ} \mathrm{C}$. Consideration of additional viscosity-composition data could result in further improvements. The combination of trend and offset to a linear correction may be advisable in future studies.

The single-component coefficients in this model have the unit $\mathrm{K} / \mathrm{mol} \%$; they correspond to the temperature change (+/-) needed by an increase of 1 mol\% oxide in exchange for $1 \mathrm{~mol} \%$ $\mathrm{SiO}_{2}$ to maintain the same viscosity. E.g. if at the glass softening point $(\log (\eta / \mathrm{Pa} \cdot \mathrm{s})=6.6) 1$ $\mathrm{mol} \% \mathrm{MgO}$ is introduced into a silicate glass in exchange for $1 \mathrm{~mol}^{\circ} \mathrm{SiO}_{2}$, the temperature may be increased $4{ }^{\circ} \mathrm{C}$ for maintaining the same viscosity due to $\mathrm{MgO}$, plus further variations due to $\mathrm{MgO}$ interactions. 
The model intercepts K0 are supposed to represent the viscosity isokom temperatures of the residual comprising mainly $\mathrm{SiO}_{2}$, and traces of minor components not considered here, such as $\mathrm{H}_{2} \mathrm{O}$, fining agents, transition element oxides etc. Glasses with silica concentrations above $\sim 85$ mol\% do not fit into this study (Table I).

Lakatos [3] was one of the first to estimate single-component influences over wide temperature ranges through a solely mathematical model with remarkable success. By including 2-, and 3-component interactions, our model is a step forward in expanding the compositional range over which glass properties may be estimated.

There are some interesting single-component influences observed in Table V. For instance, in the glass transformation range, $\mathrm{BaO}$ should not influence the viscosity whereas $\mathrm{SrO}$ should. This is supported by re-plotting experimental data of twenty-five TV panel glasses, all containing $\mathrm{SrO}$ and/or $\mathrm{BaO}$ within limited composition ranges, taken from Ref [6]. Linear relations applicable for $\log (\eta / \mathrm{Pa} \cdot \mathrm{s})=6,7,8,9,10,11$, and 12 from these data were constructed and the viscosity isokom coefficients calculated. The results, shown in Figure 1, support the premise that $\mathrm{BaO}$ and $\mathrm{SrO}$ influence viscosity less and less at lower temperatures; $\mathrm{SrO}$ substituting for $\mathrm{SiO}_{2}$ may even increase the viscosity around $\mathrm{Tg}$.

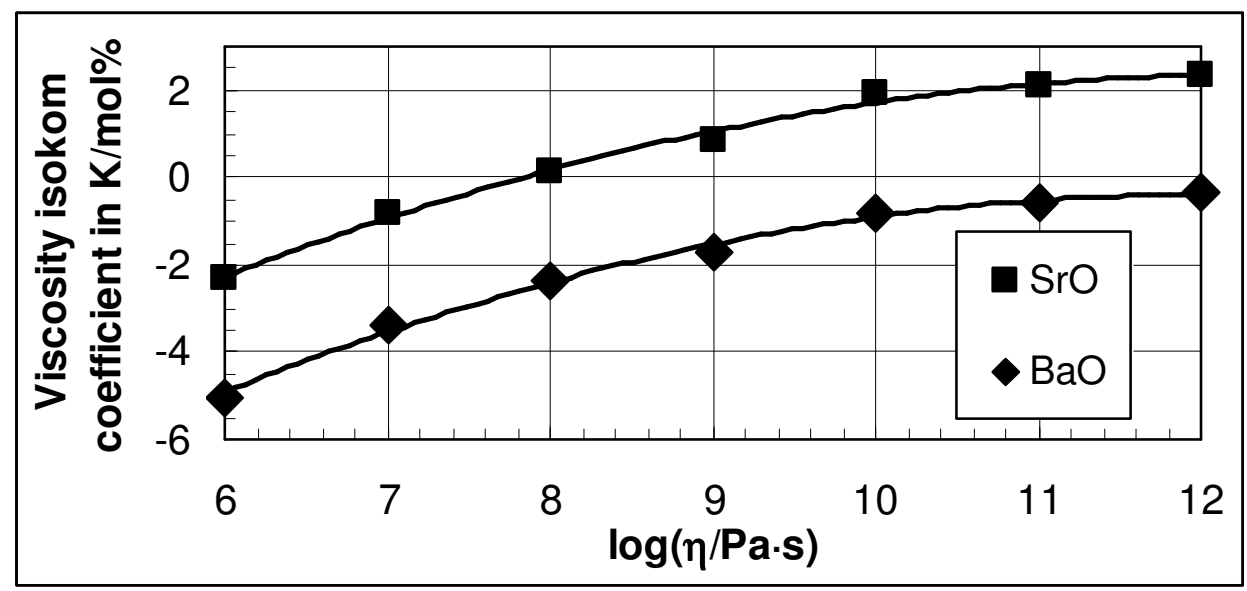

Fig. 1: Linear viscosity isokom coefficients of $\mathrm{SrO}$ and $\mathrm{BaO}$ in TV panel glasses

The fact that $\mathrm{CaO}$ increases the viscosity around $\mathrm{Tg}$, but $\mathrm{MgO}$ decreases it, is supported by Lakatos [3]. One may wonder why substitutions by $\mathrm{ZrO}_{2}$ have an insignificant influence at $\log (\eta / \mathrm{Pa} \cdot \mathrm{s})=1.5$ but significant, on the other hand, at higher viscosities. The $\mathrm{ZrO}_{2}$ concentrations in this study may be too low for a detailed analysis of the $\mathrm{ZrO}_{2}$ influence.

For direct comparisons of single-component coefficients with interaction coefficients it is necessary to calculate the square root for two-component interactions, and the cube root for three-component interactions respectively. Because many interactions had to be excluded in this work due to correlations, a model extension to additional glass composition-viscosity data is advisable.

The well-known boric oxide anomaly is represented in the models through the $\mathrm{B}_{2} \mathrm{O}_{3} * \mathrm{Na}_{2} \mathrm{O}$ and $\mathrm{B}_{2} \mathrm{O}_{3} * \mathrm{~K}_{2} \mathrm{O}$ interactions. It is known, for instance see Akimov [22], that the increase in viscosity due to alkali additions around $13 \mathrm{~mol} \%$ (a characteristic of "the boric oxide anomaly") decreases with increasing temperature. This gradual disappearance of boric oxide anomaly at higher temperatures is clearly substantiated by examining the $\mathrm{B}_{2} \mathrm{O}_{3} * \mathrm{Na}_{2} \mathrm{O}$ interactions listed in Tables III, IV and V which, actually, become negative around $\log (\eta / \mathrm{Pa} \cdot \mathrm{s})=1.5$. Besides boric 
oxide, $\mathrm{Al}_{2} \mathrm{O}_{3}$ also shows strong interactions, even though the $\mathrm{Al}_{2} \mathrm{O}_{3}$ concentrations are mostly low (Table I). Additional research is required. The well-known "mixed alkali effect" could not be analyzed so far because the influence of $\mathrm{K}_{2} \mathrm{O}$ and the $\mathrm{Na}_{2} \mathrm{O} * \mathrm{~K}_{2} \mathrm{O}$ interaction could not be isolated within the composition matrices used here. The influence of $\mathrm{Fe}_{\mathrm{x}} \mathrm{O}_{\mathrm{y}}$ could not be separated into the component contributions of the various oxidation states because of limited data.

The successful incorporation of two alkali-free borosilicate glasses mentioned in the introduction with $\mathrm{C}\left(\mathrm{SiO}_{2}\right) \sim 20 \mathrm{~mol} \%$ into the model at $\log (\eta / \mathrm{Pa} \cdot \mathrm{s})=6.6$, may demonstrate further potential of the technique established here. The influence of the two glasses on the model result was insignificant (Cook distance $<0.02$ ). Even though the chemical compositions were very uncommon, it was still possible to relate them directly to "ordinary" industrial soda-lime glasses and borosilicates through the modeling procedure. To the authors' knowledge, this was not done before without structural assumptions.

It is possible that the models presented in this study could be refined by including even those glass property data where only the batched composition is known. In particular, a large volume of Tg data could be incorporated. According to Priven [13], traditionally reported Tg for glasses may be approximated to $\log (\eta / \mathrm{Pa} \cdot \mathrm{s}) \sim 12.3$ and the current model could be shifted from $\log (\eta / \mathrm{Pa} \cdot \mathrm{s})=12.0$ to 12.3 for use in the industry.

Future extensions may also include changing to a canonical model* to describe all existing glasses, including non-oxide glasses.

\section{CONCLUSIONS}

This study is proposed to be a first step to modeling of glass properties on a global basis. In this paper, the viscosity of a large number of silicate glasses with widely varying compositions have been modeled in terms of single component influence and mutual interactions. Some important glass components are not included as yet. A number of interactions are correlated too strongly for analysis within the composition ranges covered. Notwithstanding these shortcomings, success is demonstrated in the estimation of viscosity from chemical composition

The authors thank the NSF Industry/University Center for Glass Research and the US Department of Energy (Grant DE FG 07-96EE41262) for financial support. A special thank is extended to $\mathrm{O}$. V. Mazurin for very productive discussions and encouragement of this study.

\section{REFERENCES}

${ }^{1}$ A. Winkelmann, O. Schott: "Über die Elastizität und über die Druckfestigkeit verschiedener neuer Gläser in ihrer Abhängigkeit von der chemischen Zusammensetzung"; Ann. Physik Chemie, vol. 51, 1894, p 697; and "Über thermische Widerstandscoefficienten verschiedener Gläser in ihrer Abhängigkeit von der chemischen Zusammensetzung ", vol. 51, 1894, p 730; and "Über die specifischen Wärmen verschieden zusammengesetzter Gläser", vol. 49, 1893, p 401

${ }^{2}$ A. I. Priven, O. V. Mazurin: "Comparison of methods used for the calculation of density, refractive index and thermal expansion of oxide glasses"; Glass Technol., 44 (4), 2003, p 156-166

\footnotetext{
* A canonical model would be very similar to Eq. (1). It would include silica and all silica interactions, the intercept K0 would be zero, and no squared terms would be allowed. Eq. (1) does not contain squared terms already because of strong correlations with single-component factors.
} 
${ }^{3}$ T. Lakatos, L.-G. Johansson and B. Simmingsköld, "Viscosity temperature relations in the glass system $\mathrm{SiO}_{2}-\mathrm{Al}_{2} \mathrm{O}_{3}-\mathrm{Na}_{2} \mathrm{O}-\mathrm{K}_{2} \mathrm{O}-\mathrm{CaO}-\mathrm{MgO}$ in the composition range of technical glasses"; Glass Technology Vol. 13 No. 3, June 1972, p 88-95

${ }^{4}$ Owens-Illinois Glass Company, General Research Laboratory: "Effect of Barium Oxide and Zinc Oxide on the Properties of Soda-Dolomite Lime-Silica Glass" J. Am. Ceram. Soc., vol. 25, no. 3 (1942), p 61-69; "Effect of Iron Oxide on the Properties of Soda-Dolomite Lime-Silica Glass" J. Am. Ceram. Soc., vol. 25, no. 14 (1942), p 401-408; "Effect of Substituting MgO for $\mathrm{CaO}$ on Properties of typical Soda-Lime Glasses" J. Am. Ceram. Soc., vol. 27, no. 8 (1944), p 221-225; "Effect of Fluorine and Phosphorus Pentoxide on Properties of Soda-Dolomite LimeSilica Glass" J. Am. Ceram. Soc., vol. 27, no. 12 (1944), p 369-372; "Effect of Boric Oxide on Properties of Soda-Dolomite Lime-Silica Glass" J. Am. Ceram. Soc., vol. 31, no. 1 (1948), p 814; "Effect of $\mathrm{K}_{2} \mathrm{O}$ and $\mathrm{Li}_{2} \mathrm{O}$ on Properties of Soda-Dolomite Lime-Silica Glasses" J. Am. Ceram. Soc., vol. 33, June (1950), p 181-186

${ }^{5}$ R. S. Allison, W. E. S. Turner; "Further Investigations upon the Influence of Boric Oxide on the Rate of Melting of the Batch, and on the Rate of Refining and of Setting of Commercial Glasses of the Soda-Lime-Silica Type"; J. Soc. Glass Technol., 1954, vol. 38, No. 182, p 297

${ }^{6} \mathrm{http} / / /$ www.osti.gov/servlets/purl/809193-hMVo0M/native/ (full publication in preparation)

${ }^{7}$ A. Fluegel, A. K. Varshneya, T. P. Seward, D. A. Earl "Viscosity of commercial glasses in the softening range"; in: Proceedings 7th International Conference, Advances in Fusion and Processing of Glass III (Ceramic Transactions, Volume 141; Eds.: J. R. Varner, T. P. Seward, H. Schaeffer), Rochester, New York, USA, July 27-31, 2003

${ }^{8}$ C. A. See, O. P. Lam, K. B. C. Minister, P. R. Hrma, "Viscosity of Commercial Glasses Data Package", prepared for the U.S. Department of Energy under Contract DE-AC0676RL01830, Pacific Northwest National Laboratories, March 2003

${ }^{9}$ A. K. Varshneya, "Fundamentals of Inorganic Glasses", Academic Press, Boston 1993

${ }^{10}$ A. K. Varshneya, N. H. Burlingame and W. H. Schultze, "Parallel Plate Viscometry to Study Deformation-Induced Viscosity Changes in Glass"; Glastechn. Ber. 63K (1990), 447-459

${ }^{11}$ M. B. Volf; "Mathemathical Approach to Glass"; Glass Science and Technology, vol. 9, Elsevier, 1988

$12 \mathrm{http}: / /$ cgr.alfred.edu/meltprops/meltprops.html \& http://glassproperties.com

${ }^{13}$ A. I. Priven, "Calculation of the Viscosity of Glass-Forming Melts: VI. The $\mathrm{R}_{2} \mathrm{O}-\mathrm{B}_{2} \mathrm{O}_{3}$ $\mathrm{SiO}_{2}$ and $\mathrm{RO}-\mathrm{B}_{2} \mathrm{O}_{3}-\mathrm{SiO}_{2}$ Ternary Borosilicate Systems"; Glass Physics and Chemistry, vol. 27, no. 4, 2001, p 360-370

${ }^{14}$ A. I. Priven, "Calculation of the Viscosity of Glass-Forming Melts: IV. A Unified Method for Calculating the Viscosity of Silicate and Aluminate Melts"; Glass Physics and Chemistry, vol. 24, no. 1, 1998, p 31-40

${ }^{15}$ K. C. Lyon, "Prediction of the Viscosities of Soda-Lime Silica Glasses"; J. Res. Nat. Bur. Standards A, Physics and Chemistry, vol. 78A, no. 4, July-Aug 1974, p 497-504

${ }^{16}$ D. Öksoy, D. L. Pye, E. N. Boulos; "Statistical analysis of viscosity-composition data in glassmaking" Glastech. Ber. Glass Sci. Technol. 67 (1994), no. 7, p 189-195

${ }^{17}$ H. A. Robinson, C. A. Peterson, "Viscosity of recent container glass"; J. Am. Ceram. Soc., vol. 27, no. 5, 1944, p 129

${ }^{18}$ A. Napolitano, E. G. Hawkins, "Viscosity of a standard soda-lime-silica glass"; J. Res. Nat. Bur. Stand., vol. 68A, no. 5, 1964, p 439

${ }^{19}$ O. G. Burch, C. L. Babcock, "Effect of glass color on sintering rates in manufacture of glass bottles"; J. Am. Ceram. Soc., vol. 21, no. 10, 1938, p 345 
${ }^{20}$ D. G. Montgomery, "Design and Analysis of Experiments", John Wiley \& Sons, 2001

${ }^{21}$ S. Dowdy and S. Wearden, "Statistics for Research", John Wiley \& Sons, 1983

${ }^{22} \mathrm{~V}$. V. Akimov, "Viscosity of sodium borosilicate glasses in the glass transition range", The Soviet Journal of Glass Physics and Chemistry, Fizika i Khimiya Stekla, 1991, vol. 17, no. 4, p 348; and No. 5, p 425

${ }^{23}$ C. J. R. Gonzalez-Oliver, P. S. Johnson, P. F. James, "Influence of water content on the rates of crystal nucleation and growth in Lithia-silica and soda-lime-silica glasses"; J. Mater. Sci., vol. 14, no. 5, 1979, p. 1159

\section{APPENDIX}

Table VI: Isokom temperatures in ${ }^{\circ} \mathrm{C}$ at $\log (\mathrm{\eta} / \mathrm{Pa} \cdot \mathrm{s})=1.5$ from ref. [6]; values in parentheses are extrapolated/questionable; 00 - base glasses, TV - TV panel glasses, E - E-type textile fiber glasses, LE - Low expansion borosilicate glasses, Co - Container glasses, FL - Float glasses, Wo - Wool fiber glasses

\begin{tabular}{|c|c|c|c|c|c|c|}
\hline$\#$ & TV & $\mathbf{E}$ & LE & Co & FL & Wo \\
\hline $\mathbf{0 0}$ & 1301.4 & 1273.7 & $(1690.0)^{*}$ & 1323.1 & 1299.1 & 1163.0 \\
\hline $\mathbf{0 1}$ & 1351.8 & $(1612.6)^{*}$ & $(1724.6)^{*}$ & 1458.0 & 1395.9 & $(1359.2)$ \\
\hline $\mathbf{0 2}$ & 1456.8 & 1491.8 & $(1624.2)^{*}$ & 1350.4 & 1259.5 & 1309.1 \\
\hline $\mathbf{0 3}$ & 1437.7 & 1269.3 & 1365.7 & 1205.7 & $(1316.0)$ & $(1125.0)$ \\
\hline $\mathbf{0 4}$ & 1488.6 & 1491.8 & $(1934.8)^{*}$ & 1306.4 & 1245.8 & 1281.6 \\
\hline $\mathbf{0 5}$ & 1398.2 & 1295.2 & 1446.2 & 1244.3 & 1247.5 & $(1167.3)$ \\
\hline $\mathbf{0 6}$ & 1168.8 & 1299.7 & $1480.1^{*}$ & 1218.3 & 1225.7 & $(1129.5)$ \\
\hline $\mathbf{0 7}$ & 1168.7 & $(1353.6)$ & 1467.5 & 1317.5 & 1295.0 & 1086.5 \\
\hline $\mathbf{0 8}$ & $1195.0 *$ & 1206.1 & 1342.3 & 1373.8 & 1250.4 & $(1054.1)$ \\
\hline $\mathbf{0 9}$ & 1150.1 & $(1163.8)$ & $1242.6^{*}$ & 1220.4 & 1332.7 & $(1061.8)^{*}$ \\
\hline $\mathbf{1 0}$ & 1171.7 & 1207.3 & $1503.2^{*}$ & 1345.9 & 1250.1 & $(1095.9)$ \\
\hline $\mathbf{1 1}$ & 1251.6 & 1249.3 & $1564.2^{*}$ & 1225.3 & 1236.0 & $(1100.0)$ \\
\hline $\mathbf{1 2}$ & 1195.0 & 1294.9 & $(1749.3)^{*}$ & 1352.6 & 1306.0 & 1226.1 \\
\hline $\mathbf{1 3}$ & 1241.5 & 1321.2 & $(1137.3)^{*}$ & 1304.8 & 1300.1 & 1163.0 \\
\hline $\mathbf{1 4}$ & 1122.2 & 1359.3 & 1472.2 & 1375.7 & 1291.5 & 1269.6 \\
\hline $\mathbf{1 5}$ & 1298.2 & 1424.8 & 1506.5 & 1244.7 & $1272.8 *$ & 1175.9 \\
\hline $\mathbf{1 6}$ & 1315.9 & 1506.8 & $/$ & 1392.6 & 1293.9 & 1368.6 \\
\hline $\mathbf{1 7}$ & 1158.7 & 1406.3 & $(1703.2)^{*}$ & 1225.3 & 1313.4 & 1251.7 \\
\hline $\mathbf{1 8}$ & 1237.2 & 1293.2 & $(1547.6)^{*}$ & 1258.3 & 1282.0 & $/$ \\
\hline $\mathbf{1 9}$ & 1308.6 & 1367.7 & $(1220.5)^{*}$ & 1354.2 & 1349.7 & 1104.4 \\
\hline $\mathbf{2 0}$ & 1342.8 & $/$ & $1578.0 *$ & 1394.6 & 1265.9 & 1210.1 \\
\hline $\mathbf{2 1}$ & 1236.5 & 1186.1 & 1321.9 & 1300.5 & 1327.7 & $1221.4 *$ \\
\hline $\mathbf{2 2}$ & 1276.1 & 1381.6 & $(1799.0)^{*}$ & 1400.5 & 1323.2 & $1173.9 *$ \\
\hline $\mathbf{2 3}$ & 1359.1 & 1174.7 & 1333.9 & 1294.4 & 1345.5 & 1058.3 \\
\hline $\mathbf{2 4}$ & $(1551.8)$ & $(1088.0)$ & 1270.6 & 1158.6 & 1367.9 & 963.2 \\
\hline
\end{tabular}

* Marked data had to be excluded during the regression analysis, because they were designated as outliers at one step. 
Table VII: Isokom temperatures in ${ }^{\circ} \mathrm{C}$ at $\log (\mathrm{\eta} / \mathrm{Pa} \cdot \mathrm{s})=6.6$ from ref. [6]; values in parentheses are extrapolated/questionable; 00 - base glasses, TV - TV panel glasses, E - E-type textile fiber glasses, LE - Low expansion borosilicate glasses, Co - Container glasses, FL - Float glasses, Wo - Wool fiber glasses

\begin{tabular}{|c|c|c|c|c|c|c|}
\hline$\#$ & TV & E & LE & Co & FL & Wo \\
\hline $\mathbf{0 0}$ & 700.7 & 846.2 & 806.7 & 730.8 & 721.0 & 677.8 \\
\hline $\mathbf{0 1}$ & 700.9 & $(999.6)^{*}$ & 831.6 & 765.4 & 746.8 & 724.4 \\
\hline $\mathbf{0 2}$ & 700.4 & 928.0 & $/$ & 762.5 & 705.8 & 692.8 \\
\hline $\mathbf{0 3}$ & $684.2 *$ & 861.1 & 758.8 & 681.3 & 690.3 & 657.6 \\
\hline $\mathbf{0 4}$ & 775.7 & 921.4 & 832.9 & 712.2 & 694.0 & 695.6 \\
\hline $\mathbf{0 5}$ & 787.4 & 901.3 & 763.7 & 655.9 & 688.9 & 679.4 \\
\hline $\mathbf{0 6}$ & 696.5 & 870.4 & 769.5 & 686.1 & 690.9 & 682.4 \\
\hline $\mathbf{0 7}$ & 686.7 & 819.7 & 767.6 & 710.3 & 729.8 & 671.4 \\
\hline $\mathbf{0 8}$ & $690.5 *$ & 829.7 & 752.7 & 714.9 & 707.4 & 681.8 \\
\hline $\mathbf{0 9}$ & 621.7 & 778.3 & 733.6 & 683.0 & 734.1 & 663.4 \\
\hline $\mathbf{1 0}$ & 629.9 & 827.2 & 749.1 & 720.8 & 702.9 & 676.2 \\
\hline $\mathbf{1 1}$ & 667.8 & 822.4 & 769.1 & 705.0 & 689.8 & 649.4 \\
\hline $\mathbf{1 2}$ & 671.2 & 856.7 & $829.9 *$ & 776.8 & 727.8 & 718.2 \\
\hline $\mathbf{1 3}$ & 709.2 & 872.6 & 763.4 & 685.9 & 735.0 & 654.8 \\
\hline $\mathbf{1 4}$ & 646.6 & 914.2 & 785.6 & 710.0 & 708.9 & 729.2 \\
\hline $\mathbf{1 5}$ & 703.7 & 907.1 & 792.4 & 706.9 & 699.9 & 672.7 \\
\hline $\mathbf{1 6}$ & 700.3 & 958.7 & $/$ & 751.9 & 719.5 & 713.8 \\
\hline $\mathbf{1 7}$ & 648.5 & 896.2 & 824.0 & 713.7 & 735.5 & 700.6 \\
\hline $\mathbf{1 8}$ & 702.2 & 910.2 & 779.5 & 704.6 & 708.9 & 709.0 \\
\hline $\mathbf{1 9}$ & $650.8 *$ & 844.0 & 763.7 & 728.3 & 731.8 & 687.9 \\
\hline $\mathbf{2 0}$ & 703.0 & $/$ & $/$ & 789.2 & 711.8 & 696.3 \\
\hline $\mathbf{2 1}$ & 664.3 & 823.1 & 741.1 & 711.9 & 723.0 & 706.0 \\
\hline $\mathbf{2 2}$ & 688.2 & 873.4 & $822.2 *$ & 754.7 & 742.6 & 705.8 \\
\hline $\mathbf{2 3}$ & 687.9 & 810.6 & 733.5 & 683.8 & 737.5 & 661.3 \\
\hline $\mathbf{2 4}$ & 765.9 & 779.5 & 720.8 & 662.4 & 735.5 & 627.5 \\
\hline
\end{tabular}

* Marked data had to be excluded during the regression analysis, because they were designated as outliers at one step. 
Table VIII: Isokom temperatures in ${ }^{\circ} \mathrm{C}$ at $\log (\eta / \mathrm{Pa} \cdot \mathrm{s})=12.0$ from ref. [6]; 00 - base glasses, $T V$ - TV panel glasses, E - E-type textile fiber glasses, LE - Low expansion borosilicate glasses, Co-Container glasses, FL - Float glasses, Wo-Wool fiber glasses

\begin{tabular}{|c|c|c|c|c|c|c|}
\hline$\#$ & TV & E & LE & Co & FL & Wo \\
\hline $\mathbf{0 0}$ & 521 & 663 & $554 *$ & 564 & 551 & 543 \\
\hline $\mathbf{0 1}$ & 507 & $/$ & 594 & 573 & 561 & 556 \\
\hline $\mathbf{0 2}$ & 483 & $742 *$ & $/$ & 589 & 520 & $/$ \\
\hline $\mathbf{0 3}$ & $487 *$ & 698 & 591 & 531 & 521 & 529 \\
\hline $\mathbf{0 4}$ & 558 & 709 & 579 & 540 & 538 & $/$ \\
\hline $\mathbf{0 5}$ & 591 & $699 *$ & 587 & 496 & 529 & 548 \\
\hline $\mathbf{0 6}$ & 532 & 705 & 595 & 530 & 542 & 555 \\
\hline $\mathbf{0 7}$ & 520 & 645 & 566 & $/$ & 555 & 549 \\
\hline $\mathbf{0 8}$ & 529 & $/$ & 581 & 532 & 543 & 556 \\
\hline $\mathbf{0 9}$ & 474 & 632 & 576 & 538 & 559 & $/$ \\
\hline $\mathbf{1 0}$ & 474 & 665 & 558 & 538 & 546 & 558 \\
\hline $\mathbf{1 1}$ & 496 & 654 & 570 & 552 & 528 & $/$ \\
\hline $\mathbf{1 2}$ & 498 & 677 & $583 *$ & 604 & 559 & 563 \\
\hline $\mathbf{1 3}$ & 538 & 699 & $594 *$ & 524 & 562 & 522 \\
\hline $\mathbf{1 4}$ & $496 *$ & 725 & 600 & 524 & 538 & 566 \\
\hline $\mathbf{1 5}$ & 507 & 705 & 600 & 557 & 552 & 518 \\
\hline $\mathbf{1 6}$ & 515 & 740 & $/$ & 560 & 546 & $/$ \\
\hline $\mathbf{1 7}$ & 489 & 707 & 591 & 559 & 566 & 551 \\
\hline $\mathbf{1 8}$ & 532 & 737 & 592 & 543 & 542 & 564 \\
\hline $\mathbf{1 9}$ & 473 & 658 & $553 *$ & 559 & 550 & 548 \\
\hline $\mathbf{2 0}$ & 506 & 656 & $/$ & 611 & 551 & $/$ \\
\hline $\mathbf{2 1}$ & 491 & 661 & 582 & 548 & 550 & 569 \\
\hline $\mathbf{2 2}$ & 522 & 681 & $560 *$ & 569 & 571 & 564 \\
\hline $\mathbf{2 3}$ & 502 & 652 & 566 & 523 & 552 & $/$ \\
\hline $\mathbf{2 4}$ & 520 & 630 & 571 & 517 & 554 & $/$ \\
\hline
\end{tabular}

* Marked data had to be excluded during the regression analysis, because they were designated as outliers at one step. 